\title{
Injectable platelet-rich fibrin: a new material in medicine and dentistry
}

\section{Enjekte edilebilen trombositten zengin fibrin: Tipta ve diş hekimliğinde yeni bir materyal}

\author{
Zeliha Betul Ozsagir' (1), Mustafa Tunali² \\ ${ }^{1}$ Dept. of Periodontology, University of Health Science, Faculty of Dentistry, Istanbul, Turkey, ${ }^{2}$ Dept. of Periodontology, Çanakkale Onsekiz \\ Mart University, Faculty of Dentistry, Çanakkale, Turkey
}

\begin{abstract}
Blood concentrates have been used in medicine and dentistry for many years as a wide variety of products. However, injectable platelet-rich fibrin (i-PRF), an autogenous blood concentrate found three years ago, is noteworthy. It is not difficult to predict that this completely autogenous blood concentrate, which can be used with minimally invasive methods and has many indications, will be used very widely in the future.
\end{abstract}

Key words: platelet rich fibrin, injectable platelet rich fibrin, platelet rich plasma, PRF, i-PRF, PRP

\section{O̊zet}

Kan konsantreleri tıpta ve diş hekimliğinde uzun yıllardır çok çeşitli ürünler olarak kullanılmaktadır. Buna rağmen, üç yıl önce bulunan bir otojen kan konsantresi olan enjekte edilebilen trombositten zengin fibrin (i-PRF) dikkati çekmektedir. Minimal invazif yöntemlerle kullanılabilen ve şimdiden birçok endikasyonu olan bu tamamen otojen kan konsantresinin gelecekte çok yaygın kullanılacağını tahmin etmek güç değil.

Anahtar kelimeler: trombositten zengin fibrin, enjekte edilebilir trombositten zengin fibrin, trombositten zengin plazma, TZF, E-TZF, TZP

\section{Introduction}

Platelet-rich plasma (PRP) was developed in 1954 by Kingsley as a platelet concentrate and used in the treatment of patients with severe thrombocytopenia. ${ }^{1}$ The first attempts to use concentrated platelet growth factors were made to support healing process of wounds during and after surgery. ${ }^{2,3}$ The growth factors involved in PRP and its concentration were first demonstrated in Marx and colleagues' publications in 1998 which describes the effects of platelet-rich preparation used in maxillo-facial reconstruction applications. ${ }^{4}$ Preparation of PRP varies

Corresponding author: Zeliha Betul Ozsagir, Dept. of Periodontology, University of Health Science Faculty of Dentistry, Istanbul, Turkey, Phone: +90 21641896 16, Fax Number: +90 21641896 20, E-mail: betulozsagir@hotmail.com

Received: 23 March 2020 Accepted: 26 May 2020

Conflicts of Interest: None

Funding: None

How to cite this article: $\mathrm{Ozsagir} \mathrm{ZB}$, Tunali $\mathrm{M}$. Injectable platelet-rich fibrin: a new material in medicine and dentistry. Mucosa 2020;3:27-33

(c) (i) (-) This work is licensed under a Creative Commons Attribution-NonCommercial 4.0 International License. 
according to the protocols used and takes between 3060 minutes. Two centrifugation methods are applied in PRP and during the first centrifuge, natural coagulation is prevented by tubes coated with ethylenediamine tetraacetic acid (EDTA) and citric acid (CA). After the erythrocytes are settled by the first centrifuge, in the second and rapid centrifugation process, bovine thrombin and calcium chloride or another artificial coagulant are added into the received plasma to form artificial coagulation. ${ }^{5}$ PRP is a first-generation platelet concentrate that can be used in liquid or gel form, which appears as a weak fibrin network after activation of centrifuged blood with thrombin and calcium. They are not completely autogenous products because there is an artificial addition of bovine thrombin and calcium chloride from the outside during the obtaining process. PRP has been shown to contain more than $95 \%$ platelets in its content. Platelets are cells that have a direct effect on osteoblasts, connective tissue cells, periodontal ligament cells and epithelial cells. ${ }^{6,7}$ Although PRP developers have been shown to play an important role in the release of growth factor and at different stages of wound healing, they aimed to remove leukocytes from blood concentrates. ${ }^{8}$

Disadvantages associated with the additional use of anti-coagulants which is found in PRP have been demonstrated to inhibit the wound healing process. Disadvantages of PRP;

1. Since the resulting product is not completely autogenous, it can prevent natural inflammation by creating a foreign substance reaction in the first period of wound healing. ${ }^{9}, 10$

2. The fibrin matrix structure formed by artificial coagulation is more rigid, unlike the fibrin matrix structure formed by natural coagulation. This hard structure causes the growth factors in its content to be released quickly and in a short time rather than with a controlled slow release. $^{10,11}$

3. It causes a loss of time due to its high cost and the preparation process which consists of many steps. $^{12}$
Due to the disadvantages of first-generation PRP, platelet-rich fibrin (PRF) from the second-generation blood product has emerged. PRF is obtained by centrifuging the blood which is taken into the glass coated tube without any anticoagulant additions. PRF consists of a fibrin structure in a complex threedimensional architecture where platelets, leukocytes and cytokines are concentrated. It has been asserted that $97 \%$ of platelets and $50 \%$ of leukocytes in the blood samples taken are found in the PRF clot. After centrifugation, three layers are formed; red blood cells (erythrocytes) are in the lower layer of the tube, the upper layer consists of platelet-poor plasma, and the middle layer of the tube includes platelet-rich fibrin clot. If the blood which is taken into the glass tube is put into the centrifuge late, the desired result cannot be obtained since these three natural coagulation layers will be formed without separation. ${ }^{13}$ Obtaining a completely autogenous fibrin structure has made researchers looking for better blood products rich in cytokines, growth factors and leukocytes. Various PRF materials have been developed by changing the type of the tube, the centrifuge cycle and the centrifuge time (Table 1). Due to the glass-activated fibrin network structure, it resorbs in human tissues in 7-11 days. ${ }^{14}$ However, this resorption period is sufficient only for soft tissue healing. Titanium platelet-rich fibrin (T-PRF) has been developed to eliminate the possibility of silica particles hanging in the fibrin structure in glass tube and passing to the patient. ${ }^{15,16}$ It has been shown that T-PRF can remain in the tissue for more than 30 days without resorption. It has been reported to give good results in soft tissue and bone healing because of its long resorption time and richness in growth factors. ${ }^{17}$ Advanced platelet rich fibrin types which are produced according to the low speed centrifugation concept have been shown to significantly increase the number of inflammatory cells and growth factor release. Therefore, regenerative potential has been reported to increase. ${ }^{18-20}$

Coagulation in the PRF begins with the contact of blood and the silica in the glass tube. ${ }^{11,21}$ In T-PRF, a tighter fibrin network structure is formed when the blood comes 
Table 1. Platelet-rich fibrin types

\begin{tabular}{lcclc}
\hline & Centrifugal speed & $\begin{array}{c}\text { Centrifuge } \\
\text { minute }\end{array}$ & $\begin{array}{c}\text { Tube type } \\
\text { Platelet-rich fibrin (L-PRF) }\end{array}$ & $\begin{array}{c}\text { The nature of the } \\
\text { obtained PRF }\end{array}$ \\
\hline $\begin{array}{l}\text { Titanyum platelet-rich } \\
\text { fibrin (T-PRF) }\end{array}$ & $2700 \mathrm{rpm}$ & 12 minutes & Titanyum tubes & Solid \\
\hline $\begin{array}{l}\text { Advanced platelet-rich } \\
\text { fibrin (A-PRF) }\end{array}$ & $1300 \mathrm{rpm}$ & 14 minutes & Glass tubes & Solid \\
\hline $\begin{array}{l}\text { Advanced platelet-rich } \\
\text { fibrin + (A-PRF +) }\end{array}$ & $1300 \mathrm{rpm}$ & 8 minutes & Glass tubes & Solid \\
\hline $\begin{array}{l}\text { Injectable platelet-rich } \\
\text { fibrin (i-PRF) }\end{array}$ & $700 \mathrm{rpm}$ & 3 minutes & Plastic tubes & Liquid \\
\hline
\end{tabular}

into contact with the titanium surface instead of silica. ${ }^{22}$ Compared to PRP, the only factor which restricted the usage areas of PRF is that PRF could only be produced in solid form. With the low-speed centrifugation concept, i-PRF can be obtained in liquid form without forming a PRF membrane. ${ }^{23}$ The advantages of i-PRF, the second-generation blood products, are shown in Table 2. In addition, the preparation of i-PRF can be seen in Fig. 1.

There are very few clinical studies in which i-PRF used. Albilia et al. ${ }^{30}$ stated that their study in which they used i-PRF in the temporomandibular joint showed

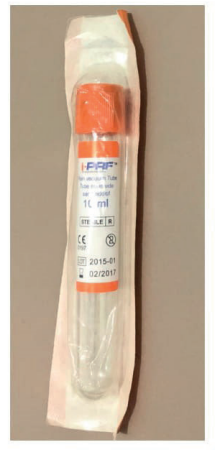

i-PRF tube

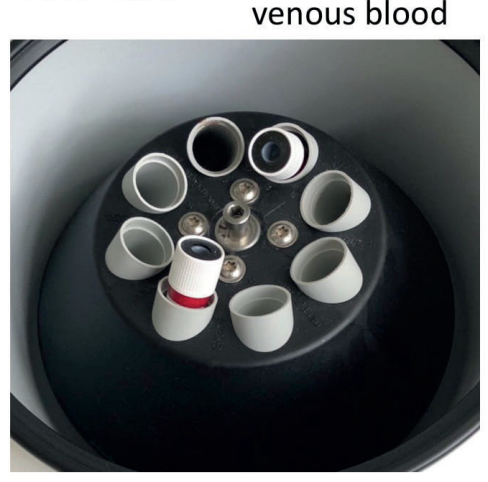

i-PRF tubes placed mutually in the centrifuge

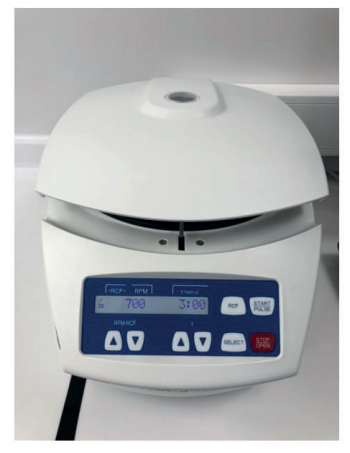

Centrifuge device

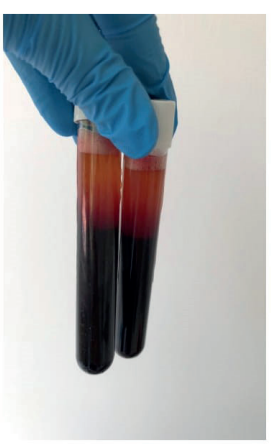

Blood separated into layers

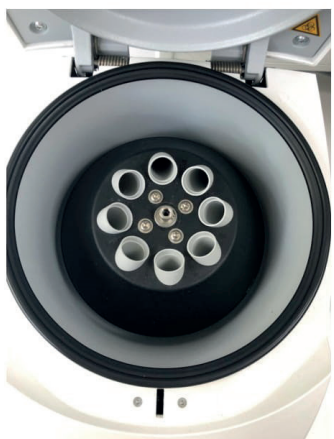

Inner chamber of the centrifuge device

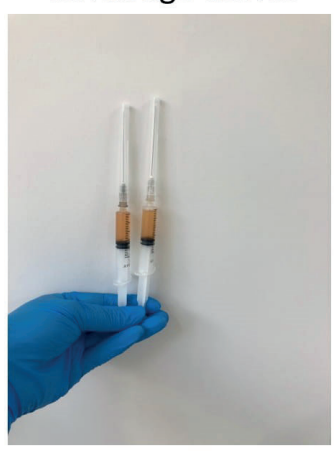

i-PRF drawn into the dental injector

Fig. 1. The preparation of i-PRF 
Table 2. i-PRF in medicine and dentistry

\begin{tabular}{|c|c|c|c|}
\hline Article & Year & Aim & Conclusion \\
\hline Miron et al. ${ }^{24}$ & 2017 & Comparing PRP with i-PRF & $\begin{array}{l}\text { Although the growth factor release was higher in the } \\
\text { PRP at the beginning, the total release was found } \\
\text { higher in the i-PRF at the end of the tenth day. They } \\
\text { showed similar tissue compatibility. While PRP was } \\
\text { associated with higher cellular proliferation, i-PRF } \\
\text { showed higher cellular migration. In cell culture, } \\
\text { i-PRF induced m-RNA expression of TGF-B and } \\
\text { collagen- } 1 \text { at } 7^{\text {th }} \text { day. }\end{array}$ \\
\hline Wang et al. ${ }^{25}$ & 2017 & $\begin{array}{l}\text { Comparison of i-PRF and PRP } \\
\text { on fibroblasts cultured on } \\
\text { titanium implant surfaces }\end{array}$ & $\begin{array}{l}\text { More cell migration, higher levels of PDGF, TGF-ß, } \\
\text { collagen-1 and fibronectin messenger RNA levels were } \\
\text { detected in i-PRF. In addition, collagen-1 synthesis } \\
\text { has been found in the highest i-PRF group. }\end{array}$ \\
\hline $\begin{array}{l}\text { Abd El Raouf et } \\
\text { al. }{ }^{26}\end{array}$ & 2017 & $\begin{array}{l}\text { Experimental rabbit study } \\
\text { to examine cartilage } \\
\text { regeneration in knee joint }\end{array}$ & $\begin{array}{l}\text { Compared to PRP and the control group, it was found } \\
\text { that in the i-PRF group, chondrocyte proliferation } \\
\text { significantly increased collagen type II and aggrecan } \\
\text { mRNA levels. }\end{array}$ \\
\hline Karde et al. ${ }^{27}$ & 2017 & $\begin{array}{l}\text { To compare the antimicrobial } \\
\text { property and platelet count } \\
\text { of i-PRF with other blood } \\
\text { products }\end{array}$ & $\begin{array}{l}\text { The inhibitory effect of PRP on the growth of oral } \\
\text { bacteria is not statistically significant. i-PRF has } \\
\text { maximum antimicrobial efficacy and higher platelet } \\
\text { count compared to other PRF and PRP. Therefore, it } \\
\text { can be said that it has a better regenerative potential. }\end{array}$ \\
\hline $\begin{array}{l}\text { Choukroun et } \\
\text { al. }{ }^{20}\end{array}$ & 2018 & $\begin{array}{l}\text { To investigate leukocyte, } \\
\text { platelet and growth factor } \\
\text { release in liquid PRF products }\end{array}$ & $\begin{array}{l}\text { Low-speed centrifugation enriches leukocytes, } \\
\text { platelets and growth factors in liquid PRF-based } \\
\text { matrices. }\end{array}$ \\
\hline Wang et al. ${ }^{28}$ & 2018 & $\begin{array}{l}\text { Comparison of PRP and i-PRF } \\
\text { in osteoblast culture }\end{array}$ & $\begin{array}{l}\text { According to the control tissue culture, PRP increased } \\
\text { osteoblast migration 2-fold and i-PRF 3-fold. } \\
\text { i-PRF showed higher osteoblast proliferation and } \\
\text { differentiation. }\end{array}$ \\
\hline Varela et al..$^{29}$ & 2018 & $\begin{array}{l}\text { To evaluate cell content, } \\
\text { morphological aspects, gene } \\
\text { expression of type I collagen } \\
\text { and release of growth factors } \\
\text { in i-PRF }\end{array}$ & $\begin{array}{l}\text { They stated that i-PRF, which includes platelets, } \\
\text { leukocytes, type I collagen, osteocalcin and growth } \\
\text { factors, can be a good approach for soft and mineralized } \\
\text { tissue healing. }\end{array}$ \\
\hline Albilia et al. ${ }^{30}$ & 2018 & $\begin{array}{l}\text { Using i-PRF in the } \\
\text { temporomandibular joint }\end{array}$ & $\begin{array}{l}\text { Pain and dysfunction in the tempromandibular joints } \\
\text { in which i-PRF is used showed a continuous decrease } \\
\text { for up to } 12 \text { months. }\end{array}$ \\
\hline Kour et al. ${ }^{31}$ & 2018 & $\begin{array}{l}\text { To evaluate the antimicrobial } \\
\text { efficacy of PRP, PRF and } \\
\text { i-PRF in Porphyromonas } \\
\text { gingivalis and Aggregatibacter } \\
\text { actinomycetemcomitans } \\
\text { strains }\end{array}$ & $\begin{array}{l}\text { They reported that PRP, PRF and i-PRF had } \\
\text { antibacterial activity, but PRP and i-PRF are more } \\
\text { active compared to PRF. }\end{array}$ \\
\hline
\end{tabular}


Table 2. Continued

\begin{tabular}{|c|c|c|c|}
\hline Tunali et al. ${ }^{32}$ & 2018 & $\begin{array}{l}\text { To compare the effect of i-PRF } \\
\text { and corticosteroid in erosive } \\
\text { lesions of oral lichen planus }\end{array}$ & $\begin{array}{l}\text { It has been found that i-PRF is similar to corticosteroid } \\
\text { injection in the treatment of erosive lesions of oral } \\
\text { lichen planus }\end{array}$ \\
\hline Gode et al. ${ }^{33}$ & 2019 & $\begin{array}{l}\text { To assess the effect of i-PRF } \\
\text { on the diced cartilage }\end{array}$ & $\begin{array}{l}\text { It has been indicated that i-PRF increased the survival } \\
\text { rate of post-operatively diced cartilage. }\end{array}$ \\
\hline Xie et al. ${ }^{34}$ & 2019 & $\begin{array}{l}\text { To investigate the regeneration } \\
\text { power of i-PRF in lateral sinus } \\
\text { operations }\end{array}$ & $\begin{array}{l}\text { It has been reported that i-PRF improved the effect of } \\
\text { osteogenesis }\end{array}$ \\
\hline Turer et al. ${ }^{35}$ & 2020 & $\begin{array}{l}\text { To assess the additional } \\
\text { contribution of i-PRF to } \\
\text { surgical operations for } \\
\text { gingival recession }\end{array}$ & $\begin{array}{l}\text { It has been stated that gingival recession decreased } \\
\text { more in the group applied i-PRF in operations with } \\
\text { coronally advanced flap with connective tissue graft. }\end{array}$ \\
\hline Ozsagir et al. ${ }^{36}$ & 2020 & $\begin{array}{l}\text { To evaluate the effect of i-PRF } \\
\text { and i-PRF }+ \text { micro-needling in } \\
\text { individuals with thin gingival } \\
\text { phenotype }\end{array}$ & $\begin{array}{l}\text { It has been indicated that } \mathrm{i}-\mathrm{PRF} \text { and } \mathrm{i}-\mathrm{PRF}+ \\
\text { microneedling application can increase gingival } \\
\text { thickness without surgical procedures in individuals } \\
\text { with thin gingival phenotype. }\end{array}$ \\
\hline
\end{tabular}

the constant reduction of pain and dysfunction in the temporomandibular joint up to 12 months. It might be due to the possibility of i-PRF having the ability to repair joint homeostasis.

Tunali et al. ${ }^{32}$ in split-mouth studies evaluated the effect of i-PRF on erosive lesions of oral lichen planus. They applied i-PRF on one side of the bilateral erosive lichen planus lesions of 13 patients and intralesional corticosteroid injection on the other side. In both i-PRF and corticosteroid groups, it was reported that pain and lesion size decreased in the control session, compared the beginning. In addition, significant statistical difference was not observed between the i-PRF and corticosteroid groups regarding the changes in pain and lesion size. It has been reported that i-PRF injection can be used instead of depot-corticosteroid injection, which has systemic and local side effects.

Gode et al. ${ }^{33}$ evaluated the effect on diced cartilage survival utilized for dorsum camouflage in rhinoplasty. They applied diced cartilage and i-PRF in the study group, and only diced cartilage in control group. It was mentioned that in cartilage measurement on ultrasound, more loss of cartilage graft thickness was observed in the control group compared to the study group. They reported that i-PRF was successful in reducing the postoperative resorption rate by increasing the viability of the diced cartilage or maintaining its form.

Xie et al. ${ }^{34}$ investigated whether the i-PRF has an additional contribution to the graft in the lateral maxillary sinus lift operation. They pointed out that i-PRF effectively reduces healing time, increases osteogenesis and it is a reliable material that can be used in maxillary sinus lift operations.

Turer et al. ${ }^{35}$ evaluated the additional contribution of i-PRF application in patients who received coronally advanced flap with connective tissue graft. They reported that i-PRF had an additional supplement to keratinized tissue width and covering the root surface. Ozsagir et al. ${ }^{36}$ used i-PRF alone and in combination with micro-needling for gingival augmentation in individuals with thin gingival phenotype. It was reported that the increase in gingival thickness was statistically significant in both groups. In the $6^{\text {th }}$ month control session, the group using i-PRF combined with micro-needling showed a statistically significant increase in gingival thickness compared to the group using only i-PRF. It is mentioned that i-PRF can be 
applied before the treatments to increase the success of periodontal plastic surgery operations and reduce the complications of orthodontic treatments.

PRP is used as an injection in areas such as knee arthroplasty, face lift surgeries, reducing the incidence of infections after heart surgeries, sports injuries, tendon/ligament injuries, osteoarthritis, meniscus healing, alopecia, musculoskeletal regenerative procedures, and acne. ${ }^{37,38}$ Since i-PRF is completely autogenous, it does not prevent natural inflammation.

In conclusion, i-PRF can be used in all areas where PRP is used and will provide a positive benefit in regeneration compared to PRP, since platelet, leukocyte and growth factors in its content are higher than PRP.

\section{References}

1. Kingsley CS. Blood coagulation; evidence of an antagonist to factor VI in platelet-rich human plasma. Nature 1954;173:723-4.

2. Anfossi G, Trovati M, Mularoni E, Massucco P, Calcamuggi G, Emanuelli G. Influence of propranolol on platelet aggregation and thromboxane B2 production from platelet-rich plasma and whole blood. Prostaglandins, leukotrienes and essential fatty acids 1989;36:1-7.

3. Fijnheer R, Pietersz R, De Korte D, et al. Platelet activation during preparation of platelet concentrates: a comparison of the platelet-rich plasma and the buffy coat methods. Transfusion 1990;30:634-8.

4. Marx RE, Carlson ER, Eichstaedt RM, Schimmele SR, Strauss JE, Georgeff KR. Platelet-rich plasma: growth factor enhancement for bone grafts. Oral Surg Oral Med Oral Pathol Oral Radiol Endod 1998;85:638-46.

5. Borzini P, Balbo V, Mazzucco L. Platelet concentrates for topical use: bedside device and blood transfusion technology. Quality and versatility. Curr Pharm Biotechnol 2012;13:1138-44.

6. Jameson CA. Autologous platelet concentrate for the production of platelet gel. Laboratory Medicine 2007;38:39-42.

7. Marx RE. Platelet-rich plasma: evidence to support its use. J Oral Maxillofac Surg 2004;62:489-96.

8. Reinke JM, Sorg H. Wound repair and regeneration. Eur Surg Res 2012;49:35-43.
9. Freire MO, Van Dyke TE. Natural resolution of inflammation. Periodontology 2000 2013;63:149-64.

10. Kasnak G, Tunali M, Firatli HE. Geçmişten günümüze kan kaynaklı ürünler ve trombositten zengin fibrinler. Turkiye Klinikleri J PeriodontolSpecial Topics 2017;3:109-12.

11. Dohan DM, Choukroun J, Diss A, et al. Plateletrich fibrin (PRF): a second-generation platelet concentrate. Part I: technological concepts and evolution. Oral Surg Oral Med Oral Pathol Oral Radiol Endod 2006;101:e37-e44.

12. Dohan Ehrenfest DM, Rasmusson L, Albrektsson T. Classification of platelet concentrates: from pure platelet-rich plasma (P-PRP) to leucocyteand platelet-rich fibrin (L-PRF). Trends Biotechnol 2009;27:158-67.

13. Dohan Ehrenfest DM, Del Corso M, Diss A, Mouhyi J, Charrier J-B. Three-dimensional architecture and cell composition of a Choukroun's plateletrich fibrin clot and membrane. J Periodontol 2010;81:546-55.

14. Choukroun J, Diss A, Simonpieri A, et al. Plateletrich fibrin (PRF): a second-generation platelet concentrate. Part IV: clinical effects on tissue healing. Oral Surg Oral Med Oral Pathol Oral Radiol Endod 2006;101:e56-60.

15. O'Connell SM. Safety issues associated with platelet-rich fibrin method. Oral Surg Oral Med Oral Pathol Oral Radiol Endod 2007;103:587.

16. Tunali M, Ozdemir H, Kucukodaci Z, Akman S, Firatli E. In vivo evaluation of titanium-prepared plateletrich fibrin (T-PRF): a new platelet concentrate. $\mathrm{Br} \mathrm{J}$ Oral Maxillofac Surg 2013;51:438-43.

17. Tunali M, Ozdemir H, Kucukodaci Z, et al. A novel platelet concentrate for guided bone regeneration: Titanium prepared platelet-rich fibrin (T-PRF). Gulhane Med J 2015;57:102-6.

18. Ghanaati S, Booms P, Orlowska A, et al. Advanced platelet-rich fibrin: a new concept for cell-based tissue engineering by means of inflammatory cells. J Oral Implantol 2014;40:679-89.

19. El Bagdadi K, Kubesch A, Yu X, et al. Reduction of relative centrifugal forces increases growth factor release within solid platelet-rich-fibrin (PRF)-based matrices: a proof of concept of LSCC (low speed centrifugation concept). Eur J Trauma Emerg Surg 2017:1-13.

20. Choukroun J, Ghanaati S. Reduction of relative centrifugation force within injectable platelet-richfibrin (PRF) concentrates advances patients' own inflammatory cells, platelets and growth factors: the first introduction to the low speed centrifugation concept. Eur J Trauma Emerg Surg 2018;44:87-95.

21. Peck M, Hiss D, Stephen L. Factors affecting the 
preparation, constituents, and clinical efficacy of leukocyte-and platelet-rich fibrin (L-PRF). SADJ 2016;71:298-302.

22. Tunali M, Ozdemir H, Kucukodaci Z, et al. A novel platelet concentrate: titanium-prepared plateletrich fibrin. Biomed Res Int 2014;2014:209548.

23. Wend S, Kubesch A, Orlowska A, et al. Reduction of the relative centrifugal force influences cell number and growth factor release within injectable PRF-based matrices. J Mater Sci Mater Med 2017;28:188.

24. Miron RJ, Fujioka-Kobayashi M, Hernandez $\mathrm{M}$, et al. Injectable platelet rich fibrin (i-PRF): opportunities in regenerative dentistry? Clin Oral Investig 2017;21:2619-27.

25. Wang X, Zhang Y, Choukroun J, Ghanaati S, Miron RJ. Behavior of gingival fibroblasts on titanium implant surfaces in combination with either Injectable-PRF or PRP. Int J Mol Sci 2017;18:331.

26. Abd El Raouf M, Wang X, Miusi S, et al. Injectable-platelet rich fibrin using the low speed centrifugation concept improves cartilage regeneration when compared to platelet-rich plasma. Platelets 2019;30:213-21.

27. Karde PA, Sethi KS, Mahale SA, Khedkar SU, Patil AG, Joshi CP. Comparative evaluation of platelet count and antimicrobial efficacy of injectable platelet-rich fibrin with other platelet concentrates: An in vitro study. J Indian Soc Periodontol 2017;21:97-101.

28. Wang X, Zhang Y, Choukroun J, Ghanaati S, Miron RJ. Effects of an injectable platelet-rich fibrin on osteoblast behavior and bone tissue formation in comparison to platelet-rich plasma. Platelets 2018;29:48-55.

29. Varela HA, Souza JCM, Nascimento RM, et al. Injectable platelet rich fibrin: cell content, morphological, and protein characterization. Clin Oral Investig 2019;23:1309-18.

30. Albilia JB, Vizcaino CH, Weisleder H, Choukroun J, Ghanaati S. Liquid platelet-rich fibrin injections as a treatment adjunct for painful temporomandibular joints: preliminary results. Cranio 2018:1-13.

31. KourP, Pudakalkatti PS, Vas AM, DasS,Padmanabhan S. Comparative evaluation of antimicrobial efficacy of platelet-rich plasma, platelet-rich fibrin, and injectable platelet-rich fibrin on the standard strains of porphyromonas gingivalis and aggregatibacter actinomycetemcomitans. Contemp Clin Dent 2018;9:325-30.

32. Tunali M, Ozsagir ZB, Unver T, Saglam E, Alinca SB, Toprak A. A new treatment approach for patients with oral lichen planus; I-PRF. J Clin Periodontol 2018;45:84-5.
33. Gode S, Ozturk A, Berber V, Kismali E. Effect of injectable platelet-rich fibrin on diced cartilage's viability in rhinoplasty. Facial Plast Surg 2019;35:393-6.

34. Xie H, Xie YF, Liu Q, Shang LY, Chen MZ. Bone regeneration effect of injectable-platelet rich fibrin (I-PRF) in lateral sinus lift: a pilot study. Shanghai Kou Qiang Yi Xue 2019;28:71-5.

35. Ucak Turer O, Ozcan M, Alkaya B, Surmeli S, Seydaoglu G, Haytac MC. Clinical evaluation of injectable platelet rich fibrin with connective tissue graft for the treatment of deep gingival recession defects: A controlled randomized clinical trial. J Clin Periodontol 2020;47:72-80.

36. Ozsagir ZB, Saglam E, Sen Yilmaz B, Choukroun J, Tunali M. Injectable platelet-rich fibrin and microneedling for gingival augmentation in thin periodontal phenotype: A randomized controlled clinical trial. J Clin Periodontol 2020;47:489-99.

37. Jain NK, Gulati M. Platelet-rich plasma: a healing virtuoso. Blood Res 2016;51:3-5.

38. Maria-Angeliki G, Alexandros-Efstratios K, Dimitris R, Konstantinos K. Platelet-rich plasma as a potential treatment for noncicatricial alopecias. Int J Trichology 2015;7:54-63. 